\title{
EFFECT ON SURVIVAL OF MICROMANIPULATING THE ZONA PELLUCIDA OF BOVINE EMBRYOS
}

\author{
M. LOPATÁR̆OVÁ, L. HOLÝ, A. VINKLER
}

Department of Animal Reproduction, Faculty of Veterinary Medicine, University of Veterinary and Pharmaceutical Sciences Brno, Czech Republic

\section{Received November 8, 2000}

Accepted February 7, 2001

\begin{abstract}
Lopatářová M., L. Holý, A. Vinkler: Effect on Survival of Micromanipulating the Zona Pellucida of Bovine Embryos. Acta Vet. Brno 2001, 70: 49-56.

Day 7 bovine embryos collected from superovulated cows were subjected to standard incision in the zona pellucida before subsequent in vitro culture for $72 \mathrm{~h}$ or direct transfer. The aim of this simple microsurgical treatment of fresh or frozen-thawed embryos of different quality was to facilitate the process of hatching. Non-treated embryos were used as controls.

Culture of zona-slit fresh grade 1 embryos yielded a higher hatched blastocyst percentage than culture of non-treated controls $[67.5 \%(54 / 80)$ vs. 57.6\% (38/66), $p>0.05]$. An even stronger effect of zona slitting was observed in grade 2 and grade 3 embryos [36.4\% (20/55) vs. $10.3 \%(7 / 68), p<0.01]$.

Culture of zona-slit frozen-thawed grade 1 embryos yielded a higher hatched blastocyst percentage than culture of non-treated controls [48.7\% (37/76) vs. $25.5 \%(12 / 47), p<0.025]$. The same applied to the effect of zona slitting of grade 2 embryos [14.4\% (13/90) vs. $2.3 \%$ $(2 / 86), \mathrm{p}<0.005]$.

The effect of zona treatment of fresh grade 1 embryos intended for immediate transfer was nonsignificant [64.6\% (42/65) survival for zona-slit vs. 63.9\% (30/61) survival for non-teated], but became apparent in the transfer of grade 2 or grade 3 embryos. Pregnancy rates for the transfer of zona-slit and non-treated embryos were $58.7 \%$ (37/63) and 47.9\% (35/73), respectively.

Pregnancy rates after transfer of frozen-thawed grade 1 embryos were higher in the group of recipients of zona-slit embryos than in controls receiving non-treated embryos [57.5\% (46/80) vs. $45.3 \%(39 / 86), p>0.05]$. No effects of zona slitting were demonstrable after transfer of frozentawed grade 2 embryos, however [30\% (18/60) vs. 33.3\% (15/45)].

The simple zona pellucida slitting procedure before in vitro embryo culture increased the survival rate in both fresh and frozen-thawed embryos. The effect was more pronounced in frozenthawed grade 1 and in fresh grade 2 and 3 embryos.
\end{abstract}

Fresh and frozen embryos, zona slitting, zona cutting, zona pellucida microsurgery

A part of bovine embryos is known not to survive after embryo transfer (B etteridge and Smith 1988). This failure significantly influences the implantation rate as well as the embryo transfer efficacy in general. The loss depends primary on the quality of embryos, which can be secondarily influenced by manipulation in vitro and/or by the environment in the recipient uterus. Approximately $20-40 \%$ of the embryos fail to survive and this percentage increases with the decrease of the morphological quality. A similar situation was observed after the transfer of frozen-thawed embryos, where cryopreservation caused damage to some cells resulting in lower quality and viability of embryos. Cryopreservation can also affect the properties of the zona pellucida (ZP) which probably becomes more resistant to natural hatching (Hoover et al. 1995).

Results of in vitro fertilization in humans (Cohen et al. 1994; Obruca 1994; Brothers et al. 1995; Menezo and Janny 1995) and laboratory animals (Gordon and Dapunt 1993; Cohen et al. 1994) indicate that blastocyst hatching may depend of the physical properties of the zona pellucida. The phenomenon called zona hardening (Hoover et al. 1995; 
Menezo and Janny 1995) interferes with hatching in due time also in a morphologically normal embryo and ranks with factors responsible for failures in embryo transfer (ET).

Morphologically imperfect or retarded embryos with normal zona quality may fail to hatch due to insufficient number of intact cells.

A number of techniques has been developed, mainly in human IVF, to prevent possible adverse effects of zona properties on hatching. They include mechanical opening (cutting, slitting, drilling) before embryo transfer using a micromanipulator (Dokras et al. 1994; Parikh et al.1996; Nakayama et al.1998; 1999; Hershlag et al. 1999), chemical treatment with acidified Tyrode solution (Liu et al.1993; Ho over et al. 1995), enzymatic thinning of the zona (Brothers et al.1995) and, in the recent years, laser. Various types of lasers such as erbium-yttrium-aluminium-garnet (Er:YAG) laser (Obruca 1994; Obruca et al. 1994; Obruca et al. 1997), non-contact 1.48 microm diode laser (Schopper et al.1999; Park et al. 1999), non-contact holmium-yttriumscandium-gallium garnet (Ho:YSGG) laser (Schiewe et al. 1995), and non-contact PALM UV laser (Antinori 1996b) are currently used for precise opening of the ZP. Novel techniques of assisted hatching (AH) include also laser zona thinning (Antin ori 1996a) or drilling of ZP by vibration of a microneedle generated in a piezomicromanipulator unit (Nakay a ma et al. 1998; 1999)

While assisted hatching has become a widely used method in human IVF and ET, it is practically unknown in animal reproduction except for partial zona dissection (PZD) enhancing the penetration of spermatozoa (Choi et al. 1994; Liow et al. 1994; Schütze et al. 1994; Clement-Sengewald et al. 1996).

The aim of this paper was to demonstrate the influence of the simple rapid manual zona pellucida dissection on in vitro and in vivo survival of in vivo produced, fresh or frozenthawed embryos of various quality.

\section{Materials and Methods}

Animals, treatment of donors and recipients

In the commercial and experimental embryo transfer the donor cows were superovulated and flushed. HolsteinFriesian cows were used for the commercial programme. Healthy donor cows were selected for and 16- to 20month-old heifers were used as recipients within the experimental programme.

The cows were superovulated in the luteal phase (between day 8-12) using eight doses of 480 - 560 I.U. (25-30 $\mathrm{mg}$ ) pro toto of FSH (Folicotropin, Spofa, Czech Republic) administered at 12-h intervals. Oestrus was induced by double prostaglandin treatment (Oestrophan, Spofa, Czech Republic) at the time of the fifth or sixth FSH treatment. Three artificial inseminations were done at 48,60 , and $72 \mathrm{~h}$ after luteolysis. Synchronisation of the recipients was achieved by prostaglandin administration one day before the donor luteolysis.

Embryo collection and scoring

Seven days after oestrus, the embryos were flushed from uterus of the donors with PBS (Dulbecco's Phosphate Buffered Saline, Live Technologies, Ltd., U.K.) + 1\% FCS (foetal calf serum, University of Veterinary and Pharmaceutical Sciences Brno, Czech Republic). The flushing as well as embryo isolation were performed as described by Holý et al. (1990).

The obtained embryos were washed with PBS $+10 \%$ FCS and evaluated for developmental stage and quality using morphological criteria. Morphologically intact compacted morulae and early blastocysts of quality 1 (morphologically intact, even granulation and cell distribution), quality 2 (small deviations, e.g. few excluded blastomeres) and quality 3 (uneven cell organisation, loosened structure with numerous free blastomeres) were used either for manipulation and subsequent in vitro culture or for direct transfer. Supernumerary embryos of quality 1 or 2 were cryopreserved. Expanded blastocysts were not manipulated due to a small or absent perivitelline space.

Micromanipulation and embryo culture

The embryos were manipulated using a stereomicroscope at 25 -fold magnification. The embryos were transferred successively from PBS $+10 \%$ FCS into a series of drops of protein-free PBS drops. In this way the embryos were attached and immobilised. In the last drop, the zona was manually carefully opened with the tip of a microsurgical knife (Plate IX, Fig.1, Feather, Japan) or with a micro-blade (made in the laboratory, tip width 5$8 \mu \mathrm{m}$ ). The length of the slash varied between $30-50 \mu \mathrm{m}$. No micromanipulator was necessary. The treated embryos (Plates IX, X, Fig. 2, 3) were either cultured in vitro or immediately transferred. 
Zona-slit and non-treated (control) morulae were washed in PBS + 10\% FCS and randomly assigned to culture in E 199 (Parker's medium with Earle's salts, Sevapharma Prague, Czech Republic) supplemented with $545 \mu \mathrm{g} / \mathrm{mL}$ Ca Lactat (Sigma), $90 \mu \mathrm{g} / \mathrm{mL}$ L-Glutamine (Sigma), $2.727 \mathrm{mg} / \mathrm{ml} \mathrm{NaHCO}{ }_{3}$ (Sigma), $1.273 \mathrm{mg} / \mathrm{mL}$ Hepes (Serva), $227 \mu \mathrm{g} / \mathrm{mL}$ Pyruvic acid (Sigma), $1 \mu \mathrm{g} / \mathrm{mL}$ Gentamycin (Sigma) and 10\% FCS. The embryos were cultured in groups in 4-well culture dishes under mineral oil (Sigma) at $39{ }^{\circ} \mathrm{C}$ in an atmosphere of $5 \% \mathrm{CO}_{2}$ in humid air for 72 h. Observations of stage of development were done at $24-\mathrm{h}$ intervals.

Freezing of embryos

The embryos were frozen in an ethylene glycol freezing solution (Voelkel and $\mathrm{Hu} 1992)(1.5 \mathrm{~mol} / \mathrm{L}$ ethylene glycol with $0.1 \mathrm{~mol} / \mathrm{L}$ sucrose, AB Technology, USA) using method of Massip et al. (1987). The HAAKE F 4Q unit was used for cryopreservation.

After thawing and morphological evaluation, a slit was made in the zona pellucida in a part of the embryos. According to the experimental protocol, a part of the embryos was cultured in vitro and another one was transferred immediately.

\section{Transfer}

Fresh or thawed embryos were transferred ipsilaterally within $1 \mathrm{~h}$ after the microsurgery. Non-treated embryos were used as controls. Rectal palpation for pregnancy was done between days 35 and 50 .

\section{Statistical analysis}

The data obtained were analysed by the chi square test $(2 \times 2$ contingency tables). The results of the analyses are summarised in Tables $1-4$.

\section{Results}

The results of culture of fresh embryos are shown in Table 1. Blastocyst and hatching stages were reached by $95 \%$ (76/80) and 76.3\% (61/80), respectively, of the zona-slit and by $90.9 \%$ $(60 / 66)$ and $65.2 \%$ (43/66), respectively, of the non-treated grade 1 embryos $(p>0.05)$.

Table 1

In vitro development of fresh D7 bovine embryos of different quality according to the zona pellucida manipulation

\begin{tabular}{|c|c|c|c|c|c|}
\hline \multirow{2}{*}{$\begin{array}{c}\text { Quality of } \\
\text { embryos }\end{array}$} & \multirow{2}{*}{$\begin{array}{c}\text { Zona pellucida } \\
\text { status }\end{array}$} & \multirow{2}{*}{$\begin{array}{c}\text { No. embryos } \\
\text { cultured }\end{array}$} & \multicolumn{3}{|c|}{ No. (\%) embryos developing to } \\
\cline { 4 - 6 } & Slitting & 80 & $76(95)$ & $61(76.3)^{\mathrm{a}}$ & $54(67.5)^{\mathrm{c}}$ \\
\hline 1 & Intact & 66 & $60(90.9)$ & $43(65.2)^{\mathrm{b}}$ & $38(57.6)^{\mathrm{d}}$ \\
\hline 1 & Slitting & 55 & $42(76.4)$ & $27(49.1)^{\mathrm{e}}$ & $20(36.4)^{\mathrm{g}}$ \\
\hline $2-3$ & Intact & 68 & $42(61.8)$ & $17(25)^{\mathrm{f}}$ & $7(10.3)^{\mathrm{h}}$ \\
\hline $2-3$ & & &
\end{tabular}

a: b, c: d not significant, $(p>0.05)$

e: $\mathrm{f}, \mathrm{g}: \mathrm{h} p<0.01$

Complete hatching was found in $67.5 \%$ (54/80) of the zona-slit and in 57.6\% (38/66) of the non-treated embryos $(p>0.05)$. The development of grade 2 and grade 3 embryos was poorer in that the blastocyst and hatching blastocyst stages were reached by $76.4 \%(42 / 55)$ and $49.1 \%$ (27/55), respectively, of the fresh zona-slit and by $61.8 \%(42 / 68)$ and $25 \%$ (17/68), respectively, of the fresh non-treated embryos. The difference in reaching the hatching blastocyst stage was highly significant $(p<0.01)$. Complete hatching was found in $36.4 \%(20 / 55)$ of the zona-slit and $10.3 \%(7 / 68)$ of the non-treated embryos $(p<0.01)$.

The results of culture of frozen/thawed embryos are shown in Table 2. Blastocyst, hatching blastocyst and hatched blastocyst stages were reached by $73.7 \%(56 / 76), 59.2 \%$ $(45 / 76)$, and $48.7 \%(37 / 76)$, respectively, of the zona-slit grade 1 embryos and by $57.4 \%$ $(27 / 47), 34 \%(16 / 47)(p<0.01)$, and 25\% (12/47) $(p<0.025)$, respectively, of the non- 
treated grade 1 embryos. The development of grade 2 frozen-thawed embryos was poorer in that the blastocyst, hatching blastocyst and hatched blastocyst stages were reached by $42.2 \%$ $(38 / 90), 30 \%(27 / 90)$, and $14.4 \%$ (13/90) of the zona-slit and by $45.3 \%(39 / 86), 9.3 \%(8 / 86)$ $(p<0.001)$, and $2.3 \%(2 / 86)(p<0.005)$ of the non-treated embryos.

Table 2

In vitro development of frozen/ thawed D7 bovine embryos of different quality according to the zona pellucida manipulation

\begin{tabular}{|c|c|c|c|c|c|}
\hline \multirow{2}{*}{$\begin{array}{c}\text { Quality of } \\
\text { embryos }\end{array}$} & \multirow{2}{*}{$\begin{array}{c}\text { Zona pellucida } \\
\text { status }\end{array}$} & $\begin{array}{c}\text { No. embryos } \\
\text { cultured }\end{array}$ & \multicolumn{3}{|c|}{ No. (\%) embryos developing to } \\
\cline { 4 - 6 } & Slitting & 76 & $56(73.7)$ & $45(59.2)^{\mathrm{a}}$ & $37(48.7)^{\mathrm{c}}$ \\
\hline 1 & Intact & 47 & $27(57.4)$ & $16(34)^{\mathrm{a}}$ & $12(25.5)^{\mathrm{d}}$ \\
\hline 1 & Slitting & 90 & $38(42.2)$ & $27(30)^{\mathrm{e}}$ & $13(14.4)^{\mathrm{g}}$ \\
\hline 2 & Intact & 86 & $39(45.3)$ & $8(9.3)^{\mathrm{f}}$ & $2(2.3)^{\mathrm{h}}$ \\
\hline
\end{tabular}

a: b $p<0.01 \mathrm{c}: \mathrm{d} p<0.025$

e: f $p<0.001 \mathrm{~g}: \mathrm{h} p<0.005$

Conception rates after the transfer of fresh embryos are summarised in Table 3. No difference was found between the conception rates of zona-slit $(64.6 \% ; 42 / 65)$ an non-treated $(63.9 \% ; 39 / 41)$ grade 1 embryos. Conception rates after the transfer of grade 2 or 3 embryos were $58.7 \%$ (37/63) for the zona-slit and 47.9\% (35/73) $(p>0.05)$ for the non-treated groups.

Table 3

Implantation rate after transfer of fresh D7 bovine embryos of different quality according to the zona pellucida manipulation

\begin{tabular}{|c|c|c|c|c|}
\hline $\begin{array}{c}\text { Quality } \\
\text { of embryos }\end{array}$ & $\begin{array}{l}\text { Zona } \\
\text { pellucida } \\
\text { status }\end{array}$ & $\begin{array}{c}\text { Embryos } \\
\text { transferred } \\
\mathrm{n}\end{array}$ & \multicolumn{2}{|c|}{$\begin{array}{l}\text { Pregnancies } \\
\mathrm{n}\end{array}$} \\
\hline 1 & Slitting & 65 & 42 & $64.6^{\mathrm{a}}$ \\
\hline 1 & Intact & 61 & 39 & $63.9^{b}$ \\
\hline $2-3$ & Slitting & 63 & 37 & $58.7^{\mathrm{c}}$ \\
\hline $2-3$ & Intact & 73 & 35 & $47.9^{d}$ \\
\hline
\end{tabular}

$\mathrm{a}: \mathrm{b}, \mathrm{c}: \mathrm{d},=$ not significant $(p>0.05)$

Table 4 summarises the results of the transfer of frozen-thawed embryos. Pregnancy rates after the transfer of grade 1 embryos were $57.5 \%$ (46/80) and 45.3\% (39/86) $(p>0.05)$ for the transfer zona-slit and the non-treated group, respectively. No significant difference was found in pregnancy rate after the transfer of zona-slit $(30 \% ; 18 / 60)$ and non-treated $(33.3 \%$; $15 / 45)$ grade 2 embryos.

\section{Discussion}

In the present experiments, the effects of microsurgical treatment of zona pellucida on in vivo development of bovine embryos were investigated. Mammalian embryos are known to develop slower and to have lower hatching rates in vitro than in vivo because culture 
Table 4

Implantation rate after transfer of frozen/ thawed D7 bovine embryos of different quality according to the zona pellucida manipulation

\begin{tabular}{|c|c|c|c|c|}
\hline $\begin{array}{c}\text { Quality } \\
\text { of embryos }\end{array}$ & $\begin{array}{l}\text { Zona } \\
\text { pellucida } \\
\text { status }\end{array}$ & $\begin{array}{l}\text { Embryos } \\
\text { transferred }\end{array}$ & \multicolumn{2}{|c|}{$\begin{array}{r}\text { Pregnancies } \\
\mathrm{n}\end{array}$} \\
\hline 1 & Slitting & 80 & 46 & $57.5^{\mathrm{a}}$ \\
\hline 1 & Intact & 86 & 39 & $45.3^{b}$ \\
\hline 2 & Slitting & 60 & 18 & $30^{c}$ \\
\hline 2 & Intact & 45 & 15 & $33.3^{\mathrm{d}}$ \\
\hline
\end{tabular}

$\mathrm{a}: \mathrm{b}, \mathrm{c}: \mathrm{d},=$ not significant $(p>0.05)$

conditions do not meet fully the requirements of the growing embryo. One of the causes that may be responsible for this difference may be the absence in culture medium of paracrine factors and proteolytic enzymes, which are present in the oviduct and the uterus (Lee et al. 1997). Our results shown in Tables 1 and 2 demonstrate an important influence of zona slitting on getting over the mechanical barrier of $\mathrm{ZP}$ and favourable effects on hatching rate in bovine embryos in vitro. They are also consistent with the observation of Lee et al. (1997), who cultured mouse embryos from the 2-cell stage in a medium enriched with 1.0 $\mu \mathrm{g} / \mathrm{mL}$ of pronase and/or $0.1 \mu \mathrm{g} / \mathrm{mL}$ proteinase and who reported a significantly higher hatching rate (60.4\% vs. $39.2 \%$ in controls). Chen et al. (1995) slit zona of mouse embryos and also observed a significantly higher percentage of completed hatching of blastocysts. Similarly, Obruca et al. (1994) reported a significantly higher hatching rate (80\% versus $29.3 \%$ ) in mouse embryos treated with Er:YAG laser after AH. The results of our in vitro and in vivo experiments are consistent with those published by Schiewe et al. (1995) who used a mouse model and found higher hatching rates $(p<0.01)$, but no significant difference in implantation rates after AH treatment. Significant differences in the development between embryos with mechanically or laser-treated and non-treated zona were reported by Park et al. (1999) and V ajta et al. (1997) who cultured bovine blastocysts in vitro (IVM/IVF/IVC).

We assume that the equal survival rate found in our experiments for zona-slit and nontreated fresh grade 1 embryos is attributable to the cell number and the quality of the embryonic cell complex with the natural expansion and hatching potentials. As shown in human IVF embryos (Lopata 1995; Menezo and Janny 1995), normally developing later embryonic stages (blastocysts) acquire hatching potential already after compaction.

In our in vivo experiments, the transfer of 63 zona-slit grade 2 and 3 embryos resulted in a higher pregnancy rate than the transfer of non-treated embryos (58.7\% vs. $47.9 \%$; $p>0.05)$. These results support the finding in mouse embryos that the hatching process may be suppressed by partial degenerative damage to embryos which may partly consist in reduced cell number (Gordon and Dapunt 1993) and partly result from adverse effects of degenerated tissue (Cohen et al. 1994).

Data published about human embryos in assisted reproduction concerning various selective criteria for $\mathrm{AH}$ mostly confirm its promoting effect on pregnancy rate (Stein et al. 1995; Žáková et al. 1996; Antinori 1996a; 1996b; Nakayama et al. 1998; 1999; Herschlag et al. 1999). On the other hand, there are studies, e.g. Hellebaut et al. (1996) denying the effect of $\mathrm{AH}$.

Herrschlag et al. (1999) found that mechanically assisted hatching of human embryos increased the pregnancy rate, but at the same time also the rate of multiple gestation. Alikani et al. (1994) observed a higher occurrence of monozygotic twins after transfer of human 
embryos whose zonae had been breached during micromanipulation for assisted fertilization or assisted hatching. Human multiple gestation frequency of $16.1 \%$ was reported also by Slotnick and Ortega (1996). Four monoamniotic twin gestations were identified from zonamanipulated cycles and one from a non-manipulated cycle. No such phenomenon was observed in our experiments; only single-foetus pregnancies resulted from all successful transfers and so far only single foetuses were born. The results of transfers of frozen/thawed grade 1 embryos also demonstrate that zona treatment contributed to better pregnancy results $(57.5 \%$ vs. $45.3 \%$, $p>0.05)$. Zona treatment in frozen/thawed grade 2 embryos had no effect on the pregnancy rate (30\% vs. $33.3 \%$ ). Published data show in agreement, that a part of embryos suffers a damage during the freezing and thawing procedures, which is manifested by reduced cell number and partial loosening of intercellular junctions. Although pulsation of the embryonic mass was observed after blastocyst thawing, the embryos were unable to leave the zona pellucida. This is probably a consequence of damage to trophoblastic cell junctions which are responsible for water flow regulation. If they are destroyed, the cells become unable to develop a pressure that is satisfactory for the zona distorsion followed by hatching. Our endeavour to support the handicapped embryos is shared by other authors. Hoover et al. (1995) pointed out the fact that the freezing-thawing procedure may have had adverse effects on physical properties of the zona pellucida (zona hardening). The increase in conception rate by $12 \%$ observed in zona-slit cryopreserved embryos was apparently due to the survival of morphologically defective blastocysts that would be lost otherwise. AH in thawed human embryos was recommended by Check et al. (1996) who demonstrated higher implantation and clinical pregnancy rates for a group treated according an $\mathrm{AH}$ protocol.

Minimal or critical numbers of cells of thawed embryos of lower morphological quality may have been important factors responsible for poor results of experiments in which the state of the zona probably played a minor role.

The use of a microinstrument instead of a micromanipulator markedly simplifies the slitting process. In the most AH procedures (Liu et al. 1993; Obruca 1994; Dokras et al.1994; Hoover et al.1995) a micromanipulation unit with two instruments was necessary. In our experience, the groove-shaped zona opening was successfully done in all selected embryos, while Parikh et al. (1996), who carried out partial mechanical dissections, reported a 1.4\% damage rate after hatching and Schütze et al. (1994), who used UV laser zona treatment found a $9 \%$ cell /PZD/ loss due to oolemma damage. Laser techniques play an important role in cell biology and biotechnology and have also been used in the polar body or blastomere biopsies in pre-implantation embryo diagnostics (Veig a et al. 1997). The prospects of laser have been demonstrated demonstrated by immobilization of spermatozoa prior to intracytoplasmic sperm injection, and successful dissection of ZP into halves with equal diameters for the hemizona assay (Schopper et al. 1999). For the simple zona drilling, we do not find the expensive laser equipment (Obruca 1994; Schütze et al.1994; Schiewe et al. 1995; Obruca et al. 1997; Schopper et al. 1999; Park et al. 1999) necessary.

In comparison with non-treated embryos, zona pellucida manipulation before embryo transfer of fresh, slightly defective, as well as of frozen-thawed, morphologically normal embryos increased the survival rate.

The method of zona pellucida dissection is simple, rapid, and inexpensive and can be routinely used in human and veterinary reproductive medicine.

\section{Přežívání embryí skotu po mikromanipulačním narušení zona pellucida}

U embryí skotu různé morfologické kvality, získaných za sedm dní po superovulaci, byla naříznuta zona pellucida a takto ošetřené zárodky byly bud' kultivovány in vitro po dobu 72 hodin, nebo byly přímo přenášeny do dělohy př́ijemce. Cílem tohoto jednoduchého mikrochirurgického zásahu, který jsme provedli jak u čerstvých, tak i rozmrazených embryí, 
bylo usnadnění procesu klubání (hatching) a vyklubání zárodků a tím i ovlivnění jejich přežívání. Výsledky byly srovnány s kontrolními, nemanipulovanými embryi.

Během kultivace čerstvých, morfologicky dobrých (quality grade 1) zárodků, dosáhlo po mikromanipulaci stádia vyklubané blastocysty 67,5\% (54/80), zatímco u neošetřených embryí dosáhlo tohoto stádia 57,6\% (38/66) ( $p>0.05)$. Mikromanipulovaná embrya horších kvalit (quality grade 2-3) dosáhla vyklubané blastocysty ve 36,4\% (20/55), nemanipulované kontroly se vyklubaly jen v 10,3\% (7/68) případů $(p<0.01)$.

Zmrazená-rozmrazená embrya dobré kvality s uměle narušenou zonou se in vitro vyvíjela do vyklubané blastocysty ve 48,7\% (37/76), zatímco neošetřená embrya dosáhla vyklubání jen ve $25,5 \%$ (12/47) případů $(p<0.025)$. Embrya horší kvality (grade 2$)$ se po ošetř̌ení zona pellucida vyklubala ve 14,4\% (13/90), embrya neošetřená dosáhla hatching rate jen 2,3\% $(2 / 86)$ př́ipadů $(p<0.005)$.

Po přenosu čerstvých, morfologicky intaktních embryí s ošetřenou resp. neošetřenou zonou bylo dosaženo stejných výsledků, protože koncipovalo 64,6\% (42/65) resp. 63,9\% (30/61) př́jemcủ. Celkem 58,7\% (37/63) březostí bylo získáno po přenosu manipulovaných čerstvých embryí s morfologickými odchylkami (quality grade 2 nebo 3), ale po přenosu kontrolních embryí zabřezlo pouze 47,9\% (35/73) zvírat.

Po přenosu zmrazených-rozmrazených embryí dobré kvality s naříznutou zonou bylo dosaženo 57,5\% (46/80) gravidit, oproti 45,3\% (39/86) koncepci v kontrolní skupině ( $p>$ 0.05). Naproti tomu, úroveň gravidity byla stejná - 30\% (18/60) resp. 33,3\% (15/45) - když byla přenášena zmrazená-rozmrazená embrya nižší morfologické kvality (2) s ošetřenou nebo neošetřenou zona pellucida.

Dosažené výsledky ukazují, že jednoduché naříznutí zona pellucida před kultivací in vitro zvyšuje přežívání jak u čerstvých, tak i rozmrazených embryí všech morfologických kategorií. Po transferu čerstvých embryí nižší morfologické kvality a rozmrazených morfologicky normálních embryí byla potvrzena lepší úroveň přežívání po manipulaci zona pellucida proti kontrolám.

\section{Acknowledgement}

This study was supported by a grant of the Czech Ministry of Education, Youth, and Sports (Project No. 161700002).

\section{References}

ALIKANI, M., NOYES, N., COHEN, J., ROSENWAKS, Z. 1994: Monozygotic twinning in the human is associated with the zona pellucida architecture. Hum. Reprod. 9: 1318-1321

ANTINORI, S., PANCI, C., SELMAN, HA., CAFFA, B., DANI, G., VERSACI, C. 1996a: Zona thinning with the use of laser: a new approach to assisted hatching in humans. Hum. Reprod. 11: 590-594

ANTINORI, S., SELMAN, HA., CAFFA, B., PANCI, C., DANI, G., VERSACI, C. 1996b: Zona opening of human embryos using a non-contact UV laser for assisted hatching in patients with poor prognosis of pregnancy. Hum. Reprod. 11: 2488-2492

BETTERIDGE, KJ., SMITH, C. 1988: Extending the use of embryo transfer in farm animals. Proc. XIth. Int. Congr. Anim. Reprod. and A.I. Dublin 5: 255-263

BROTHERS, AJ., SHER, G., ZOUVES, C., WILLMAN, S., KUTTNER, G., ULEHLOVA, E., WATERHOUSE, K., HUEN, N. 1995: A gentle enzymatic method for assisted hatching to enhance implantation. J. Assist. Reprod. Genet. 12: 105

CHECK, JH., HOOVER, L., NAZARI, A., O'SHAUGHNESSY, A., SUMMERS, D. 1996: Effect of assisted hatching on pregnancy rates after frozen embryo transfer. Fertil. Steril. 65: 254-257

CHEN, SU., HO, HN., CHEN, HF., CHAO, KH., WU, MY., HUANG, SC., LEE, TY., YANG, ZS. 1995: Effect of assisted hatching by partial zona pellucida dissection on mouse embryos in vitro. J. Formosan Medical Association 94: 463-468

CHOI, ZH., HOCHI, S., BRAUN, J., OGURI, N. 1994: In vitro fertilization of partially zona dissected or partially zona removed equine oocytes. Theriogenology 41: 177

CLEMENT- SENGEWALD, A., SCHUTZE, K., ASHKIN, A., PALMA, GA., KERLEN, G., BREM, G. 1996: Fertilization of bovine oocytes induced solely with combined laser microbeam and optical tweezers. J. Assist. Reprod. Genet. 13: 259-265 
COHEN, J., ALIKANI, M., LIU, HC., ROSENWAKS, Z. 1994: Rescue of human embryos by micromanipulation. Baillieres Clin. Obstet. Gynaecol. 8: 95-116

DOKRAS, A., ROSS, C., GOSDEN, B., SARGET, IL., BARLOW, DH. 1994: Micromanipulation of human embryos to assist hatching. Fertil. Steril. 61: 514-520

GORDON, JW, DAPUNT, U. 1993: A new mouse model for embryos with a hatching deficiency and its use to elucidate the mechanism of blastocyst hatching. Fertil. Steril. 59: 1296-1301

GORDON, JW., GANG, I. 1990: Use of zona drilling for safe and effective biopsy of murine oocytes and embryos. Biology of Reproduction 42: 869- 876

HELLEBAUT, S., DE SUTTER, P., DOZORTSEV, D., ONGHENA, A., QIAN, C., DHONT, M. 1996: Does assisted hatching improve implantation rates after in vitro fertilization or intracytoplasmic sperm injection in all patient? A prospective randomized study. J. Assist. Reprod. Genet. 13: 19-22

HERSHLAG, A., PAINE, T., COOPER, GW., SCHOLL, GM., RAWLINSON, K., KVAPIL, G. 1999: Monozygotic twining associated with mechanical assisted hatching. Fertil. Steril. 71: 144-146

HOLÝ, L., LOPATÁR̃́OVÁ, M., KRONTORÁD, P., HOLÝ, J. 1990: Systematische Anwendung des Embryotransfers beim Rind unter den Bedingungen großer Tierkonzentrationen. Mh. Vet.-Med. 45: 409-413

HOOVER, L., SUMMERS, D., CHECK. JH., NAZARI, A., O'SHAUGHNESSY, A. 1995: Pregnancy after zona drilling of cryopreserved thawed embryos. J. Assist. Reprod. Genet. 12: 182

LEE, DR., LEE, JE., YOON, HS., LEE, HJ., KIM, MK., ROH, SI. 1997: The supplementation of culture media with protease improves the hatching rate of mouse embryos. Hum. Reprod. 12: 2493- 2498

LIOW, SL., VASUTHEVAN, S., TOK, V., BONGSO, A., RATNAM, SS. 1994: Laser zona cutting of mouse oocytes. Theriogenology 41: 239

LIU, HC., COHEN, J., ALIKANI, M., NOYES, N., ROSENWAKS, Z. 1993: Assisted hatching facilitates earlier implantation. Fertil. Steril. 60: 871-875

LOPATA, A. 1995: The biology and clinical practice of blastocyst implantation. J. Assist. Reprod.Genet. 12: 4

MASSIP, A., VAN DER ZWALMEN, P., ECTORS, F. 1987: Recent progress in cryopreservation of cattle embryos. Theriogenology 27: 69-79

MENEZO, Z., JANNY, L. 1995: How can we modulade the IVF technology according to the indication? J. Assist. Reprod. Genet. 12: 9

NAKAYAMA, T., FUJIWARA, H., TASTUMI, K., FUJITA, K., HIGUCHI, T., MORI, T. 1998: A new assisted hatching technique using a piezo-micromanipulator. Fertil. Steril. 69: 784-788

NAKAYAMA, T., FUJIWARA, H., YAMADA, S., TASTUMI, K., HONDA, T., FUJII, S. 1999: Clinical administration of a new assisted hatching using a piezo-micromanipulator for morphologically low-quality embryos in poor-prognosis infertile patients. Fertil. Steril. 71: 1014- 1018

OBRUCA, A. 1994: Eclosion et microfecondation assistees. Contracept. Fertil. Sex. 22: 303- 305

OBRUCA, A., STROHMER, H., SAKKAS, D., MENEZO, Y., KOGOSOWSKI, A., BARAK,Y., FEICHTINGER, W. 1994: Use of laser in assisted fertilization and hatching. Hum. Reprod. 9: 1723-1726

OBRUCA, A., STROHMER, H., BLASCHITZ, A., SCHONICKLE, E., DOHR, G., FEICHTINGER, W. 1997 Ultrastructural observations in human oocytes and preimplantation embryos after zona opening using an erbiumyttrium-aluminium-garnet (Er:YAG) laser. Hum. Reprod. 12: 2242-2245

PARIKH, FR., KAMAT, SA., NADKARNI, S., ARAWANDEKAR, D., PARIKH, RM. 1996: Assisted hatching in an in vitro fertilization programme. J. Assist. Reprod. Genet. Suppl. 50: 121-125

PARK, S., KIM, EY., YOON, SH., CHUNG, KS., LIM, JH. 1999: Enhanced hatching rate of bovine IVM/IVF/IVC blastocysts using a 1.48-micron diode laser beam. J. Assist. Reprod. Genet. 16: 97-101

SCHIEWE, MC., NEEV, J., HASELEGER, NL., BALMACEDA, JP., BERNS, MW., TADIR, Y. 1995: Developmental competence of mouse embryos following zona drilling using a non-contact holmium: yttrium scandian gallium garnet (Ho: YSGG) laser system. Hum. Reprod. 10: 1821- 1824

SCHOPPER, B., LUDWIG, M., EDENFELD, J., AL-HASANI, S., DIETRICH, K. 1999: Possible administration of lasers in assisted reproductive technologies. Hum. Reprod. Suppl. 14: 186-193

SCHÜTZE, K., CLEMENT-SENGEWALD, A., ASHKIN, A. 1994: Zona drilling and sperm insertion with combined laser microbeam and optical tweezers. Fertil. Steril. 61: 783-786

SLOTNICK, RN., ORTEGA, JE. 1996: Monoamniotic twinning and zona manipulation: a survey of U.S. IVF centers correlating zona manipulation procedures and high-risk twinning frequency. J. Assist. Reprod. Genet. 13: $381-385$

STEIN, A., RUFAS, O., AMIT, S., AVRECH, O., PINKAS, H., OVADIA, J., FISCH, B. 1995: Assisted hatching by partial zona dissection of human pre-embryos in patients with recurrent implantation failure after in vitro fertilization. Fertil. Steril. 63: 838-841

VAJTA, G., HOLM, P., GREVE, T., CALLESEN, H. 1997: Survival and development of bovine blastocysts produced in vitro after assisted hatching, vitrification and in-straw direct rehydration. J. Reprod. Fertil. 111: 65-70

VEIGA, A., SANDALINAS, M., BENKHALIFA, M. 1997: Laser blastocyst biopsy for preimplantation diagnosis in the human. Zygote 5:351-354

VOELKEL, SA., HU, YX. 1992: Direct transfer of frozen-thawed bovine embryos. Theriogenology 37: 23-37

ŽÁKOVÁ, J., VENTRUBA, P., ADLER, J. TRÁVNÍK, P., NĚMCOVÁ, S. 1996: Assisted hatching - a useful micromanipulation technic in women after repeated failure of embryo transfer. Česká gynekologie 61: 6-9 
Plate IX

Lopatářová M. et al.: Effect... pp. 49-56

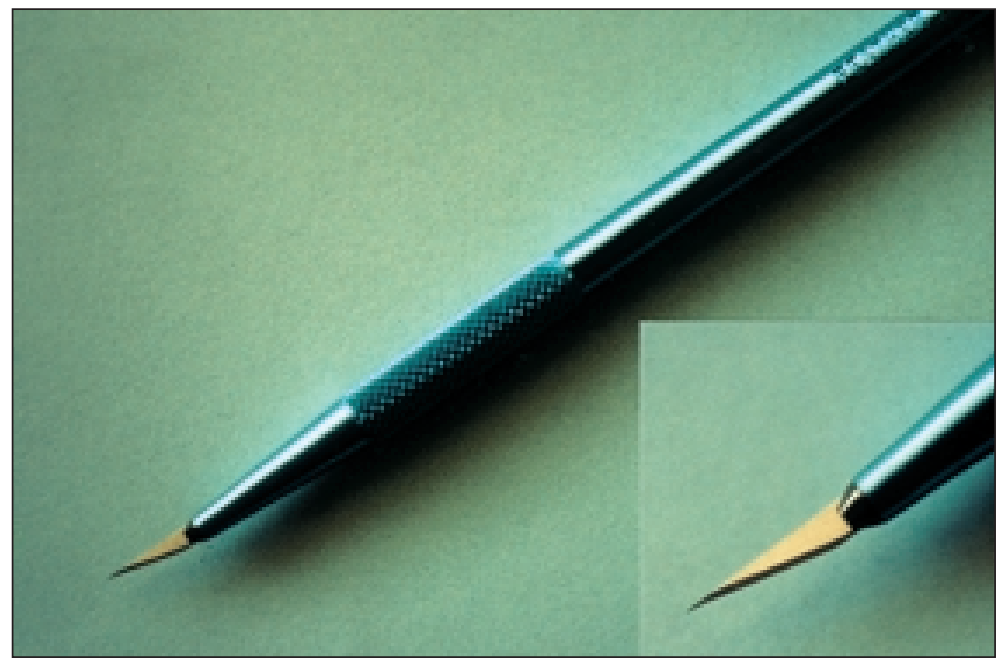

Fig. 1. Microsurgical blade for zona slitting

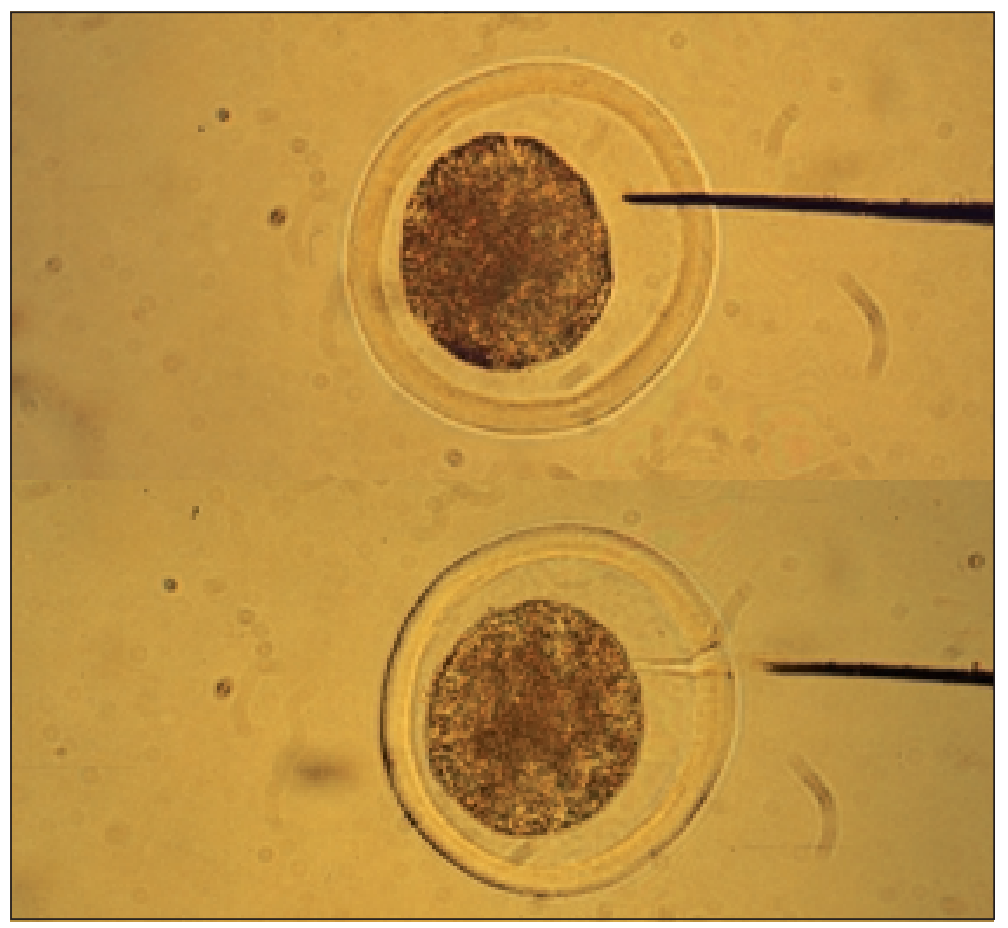

Fig. 2. Zona slitting of a good quality bovine embryo 
Plate X

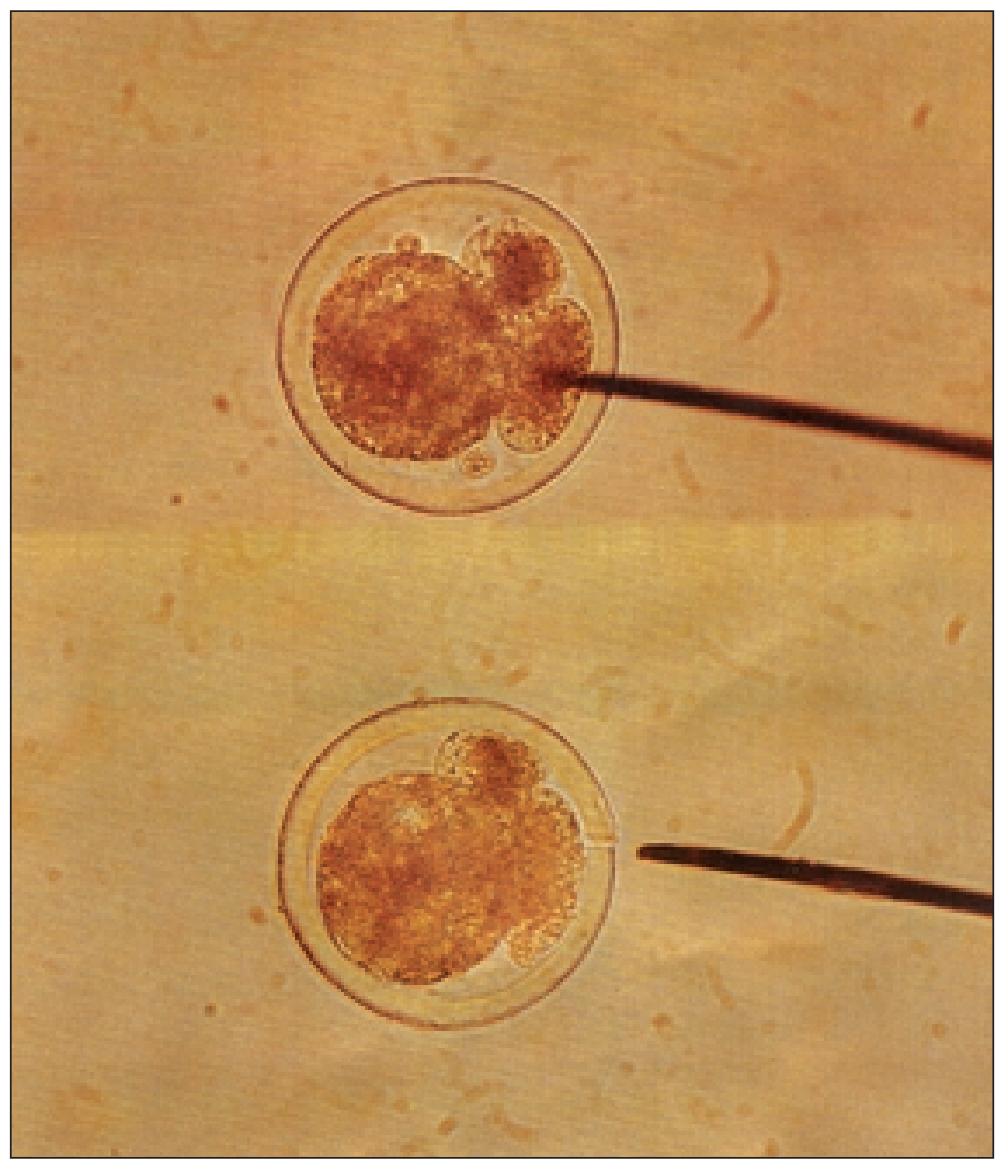

Fig. 3. Zona slitting of a lower quality bovine embryo 